\title{
PEPTIDE BOND FORMATION THROUGH GAS-PHASE REACTIONS IN THE INTERSTELLAR MEDIUM: FORMAMIDE AND ACETAMIDE AS PROTOTYPES
}

\author{
Pilar Redondo, Carmen Barrientos, and Antonio Largo \\ Computational Chemistry Group, Departamento de Química Física, Facultad de Ciencias, \\ Universidad de Valladolid, E-47011 Valladolid, Spain; predondo@qf.uva.es \\ Received 2014 June 18; accepted 2014 July 24; published 2014 September 2
}

\begin{abstract}
A theoretical study of the reactions of $\mathrm{NH}_{4}^{+}$with formaldehyde and $\mathrm{CH}_{5}^{+}$with formamide is carried out. The viability of these gas-phase ion-molecule reactions as possible sources of formamide and acetamide under the conditions of interstellar medium is evaluated. We report a theoretical estimation of the reaction enthalpies and an analysis of their potential energy surfaces. Formation of protonated formamide from the reaction between ammonium cation and formaldehyde is an exothermic process, but all the channels located on the potential energy surface leading to this product present net activation energies. For the reaction between methanium and formamide, different products are possible from a thermodynamic point of view. An analysis of its potential energy surface showed that formation of protonated acetamide and amino acetaldehyde takes place through barrier-free paths. Therefore, this reaction could be a feasible source of acetamide and amino acetaldehyde in space.
\end{abstract}

Key words: astrobiology - astrochemistry - ISM: kinematics and dynamics - ISM: molecules molecular processes

Online-only material: color figures

\section{INTRODUCTION}

The synthesis of biomolecules under prebiotic conditions is currently one of the most interesting research subjects because it is directly related to the origin of life. In this context, a key step is the formation of peptide bonds between amino acids for obtaining proteins that are essential components of all living systems. In spite of the large number of interstellar molecules detected in space (today more than 170 species), detection of even the simplest amino acid, glycine, still remains to be confirmed (Ceccarelli et al. 2000; Hollis et al. 1980, 2003a, 2003b; Kuan et al. 2003; Snyder et al. 2005). It should be taken into account that even glycine is a relatively complex molecule, and therefore its rotational spectrum has relatively weak lines (Irvine 1998). In this sense, the availability of modern radio telescopes together with interferometry methods could facilitate its detection. In addition, the presence of amino acids in several meteorites suggests the possibility of producing them in extraterrestrial environments.

Among the organic molecules detected in space, there are two molecules with a peptide bond $(\mathrm{NH}-\mathrm{C}=\mathrm{O})$, formamide (Rubin et al. 1971) and acetamide (Hollis et al. 2006). These simple molecules are important as prototypes for understanding peptide bond formation in the interstellar medium. Formamide and acetamide with both amino and carbonyl sites are expected to play a key role in the origin of life. In this way, Saladino et al. (2012) have pointed out that formamide may provide all the components necessary for the formation of nucleic polymers under prebiotic conditions. A theoretical study shows that the decomposition of formamide generates small molecules, which are useful intermediates in the prebiotic synthesis of biomolecules (Nguyen et al. 2011, 2013). The knowledge of the mechanisms involved in the formation of these simple species is essential to understanding more complex molecular evolution. The chemistry in interstellar environments is limited by the low densities and temperatures, making research in theoretical chemistry very useful in the field of astrochemistry.
Different theoretical and experimental works have been devoted to the formamide formation through gas-phase reactions or on the surface of interstellar grains. Formamide has been experimentally obtained from binary ice mixtures of $\mathrm{CO}$ and $\mathrm{NH}_{3}$ irradiated by energetic particles as electrons (Jones et al. 2011). Garrod et al. (2008) proposed a new gas-grain chemical network, in which a wide array of complex species may be formed by reactions involving radicals. Formamide is formed on grain surfaces at low temperatures by successive hydrogenation of accreted OCN. They also considered its gas-phase formation through the radical-neutral reaction between $\mathrm{H}_{2} \mathrm{CO}$ and $\mathrm{NH}_{2}$, but it presents net activation energy. A theoretical study of the reaction between $\mathrm{HCOOH}$ and $\mathrm{NH}_{3}$ in both gas phase and ices to yield formamide was carried out by Woon (2001), but the most favorable process was found to be the formation of $\mathrm{NH}_{2} \mathrm{CH}(\mathrm{OH})_{2}$. Chen \& Woon (2011) also performed a theoretical study of the gas-phase reaction between $\mathrm{H}_{2} \mathrm{CO}$ and $\mathrm{NH}_{3}$. They showed that the energy barrier was lowered if the reaction took place on the surface of glace, using a model system with up to $12 \mathrm{H}_{2} \mathrm{O}$ molecules. In a recent theoretical study, we analyzed different gas-phase reactions that could yield formamide precursors (Redondo et al. 2014). The most favorable reactions from a thermodynamic point of view were the reactions of protonated neutral and ionized hydroxylamine with formaldehyde. However, the analysis of their potential energy surfaces showed that they were not viable processes under interstellar conditions.

Less is known about possible synthetic routes of acetamide in space. Hollis et al. (2006) proposed that the exothermic reaction of formamide with the methylene radical could account for the synthesis of interstellar acetamide, although this reaction involves a spin flip on the $\mathrm{CH}_{2}$ radical and would not proceed under low temperatures. Quan \& Herbst (2007) suggested that formamide and acetamide could be synthetized through radiative association reactions. The reaction of formaldehyde with protonated ammonia has been proposed to obtain formamide. Concerning acetamide, the reactions of either formamide with 
$\mathrm{CH}_{3}^{+}$or acetaldehyde with ammonium ion were suggested. The ions formed in these reactions could give formamide and acetamide upon dissociative recombination. However, there are not available results for these reactions, and the estimated rate constants produce abundances lower than those experimentally determined. Recently, Halfen et al. (2011) have carried out extensive observations of acetamide and formamide toward Sgr B2(N). The similarity between the determined abundances and distribution of acetamide and formamide suggests a synthetic connection. They suggested that the following processes might lead to formamide and acetamide:

$$
\begin{gathered}
\mathrm{H}_{2} \mathrm{CO}+\mathrm{NH}_{4}^{+} \rightarrow \mathrm{NH}_{3} \mathrm{CHO}^{+}+\mathrm{H}_{2}, \\
\mathrm{NH}_{3} \mathrm{CHO}^{+}+e^{-} \rightarrow \mathrm{NH}_{2} \mathrm{CHO}+\mathrm{H} \\
\mathrm{NH}_{2} \mathrm{CHO}+\mathrm{CH}_{5}^{+} \rightarrow \mathrm{CH}_{3} \mathrm{CONH}_{3}^{+}+\mathrm{H}_{2}, \\
\mathrm{CH}_{3} \mathrm{CONH}_{3}^{+}+e^{-} \rightarrow \mathrm{CH}_{3} \mathrm{CONH}_{2}+\mathrm{H}
\end{gathered}
$$

The validation of this mechanism depends on the viability of these reactions in space. However, with the only exception of the estimated reaction enthalpy for reaction (1) that we have reported in our previous work about synthetic routes of formamide formation (Redondo et al. 2014), there are not available theoretical or experimental results for the ion-molecule reactions proposed.

The objective of this work is to theoretically analyze the viability in the interstellar medium of the gas phase ion-molecule reactions, (1) and (3), which could produce protonated formamide and acetamide, respectively. First, a theoretical estimation of the reaction enthalpies for the proposed processes considering different products is reported. Second, we perform a theoretical study of the potential energy surface in order to determine if they are barrier-free processes.

\section{COMPUTATIONAL METHODS}

Potential energy surfaces for the ion-molecule reactions proposed in this study are analyzed. Stationary points on each surface, namely, reactants, intermediates, transition states, or products, are located at the Møller-Plesset level (MP2; Møller \& Plesset 1934) in conjunction with Dunning's aug-cc-pVTZ (correlation-consistent polarized valence triple-zeta including diffuse functions) basis set (Dunning 1989; Woon \& Dunning 1993). Energy of the stationary points are refined by single point calculations at coupled-cluster level with singles and doubles and a perturbative inclusion of triple excitations $(\operatorname{CCSD}(\mathrm{T})$; Raghavachari et al. 1989) employing the aug-cc-pVTZ, and augcc-pVQZ (correlation-consistent polarized valence quadruplezeta including diffuse functions) bases (Dunning 1989; Woon \& Dunning 1993).

Minima and transition states are characterized by the analysis of the computed harmonic vibrational frequencies carried out at the MP2/aug-cc-pVTZ level. Zero negative eigenvalues of the analytical Hessian corresponds to a local minimum and one negative eigenvalue to a first-order saddle point. The calculated harmonic vibrational frequencies also allow us to estimate the zero-point vibrational energy (ZPVE) correction for each structure. To confirm that transition states connect the desired minima, an intrinsic reaction coordinate (IRC; Fukui 1981) has been calculated for each one.

All results reported in this work were obtained by using the Gaussian-09 program package (Frisch et al. 2009).
Table 1

Reaction Enthalpies for the Gas-phase Reaction $\mathrm{NH}_{4}^{+}\left({ }^{1} \mathrm{~A}^{\prime}\right)+\mathrm{H}_{2} \mathrm{CO}\left({ }^{1} \mathrm{~A}_{1}\right)$ Calculated at $0 \mathrm{~K}$

\begin{tabular}{lccr}
\hline \hline Products & $\begin{array}{c}\Delta H^{\mathrm{a}} \\
\left(\mathrm{kcal} \mathrm{mol}^{-1}\right)\end{array}$ & $\begin{array}{c}\Delta H^{\mathrm{b}} \\
\left(\mathrm{kcal} \mathrm{mol}^{-1}\right)\end{array}$ & $\begin{array}{c}\Delta H^{\mathrm{c}} \\
\left(\mathrm{kcal} \mathrm{mol}^{-1}\right)\end{array}$ \\
\hline $\mathrm{NH}_{2} \mathrm{CHOH}^{+}\left({ }^{1} \mathrm{~A}^{\prime}\right)+\mathrm{H}_{2}\left({ }^{1} \Sigma_{\mathrm{g}}^{+}\right)$ & -3.17 & -3.12 & -3.68 \\
$\mathrm{NH}_{3} \mathrm{CHO}^{+}\left({ }^{1} \mathrm{~A}^{\prime}\right)+\mathrm{H}_{2}\left({ }^{1} \Sigma_{\mathrm{g}}^{+}\right)$ & 12.52 & 12.91 & 12.89 \\
$\mathrm{NH}_{2} \mathrm{OCH}_{2}^{+}\left({ }^{1} \mathrm{~A}^{\prime}\right)+\mathrm{H}_{2}\left({ }^{1} \Sigma_{\mathrm{g}}^{+}\right)$ & 80.42 & 76.18 & 76.80 \\
$\mathrm{OH}_{2} \mathrm{NCH}_{2}^{+}\left({ }^{1} \mathrm{~A}^{\prime}\right)+\mathrm{H}_{2}\left({ }^{1} \Sigma_{\mathrm{g}}^{+}\right)$ & 77.38 & 72.62 & 73.12 \\
$\mathrm{OHNHCH}_{2}^{+}\left({ }^{1} \mathrm{~A}\right)+\mathrm{H}_{2}\left({ }^{1} \Sigma_{\mathrm{g}}^{+}\right)$ & 56.00 & 52.75 & 52.59 \\
$\mathrm{OHNCH}_{3}^{+}\left({ }^{1} \mathrm{~A}\right)+\mathrm{H}_{2}\left({ }^{1} \Sigma_{\mathrm{g}}^{+}\right)$ & 94.19 & 88.64 & 89.05 \\
$\mathrm{NH}_{2} \mathrm{CH}_{2} \mathrm{OH}^{+}\left({ }^{2} \mathrm{~A}\right)+\mathrm{H}\left({ }^{2} \mathrm{~S}\right)$ & 95.64 & 93.27 & 93.83 \\
$\mathrm{NH}_{3} \mathrm{CH}_{2} \mathrm{O}^{+}\left({ }^{2} \mathrm{~A}^{\prime \prime}\right)+\mathrm{H}\left({ }^{2} \mathrm{~S}\right)$ & 97.10 & 92.56 & 93.58 \\
$\mathrm{NH}_{2} \mathrm{OCH}_{3}^{+}\left({ }^{2} \mathrm{~A}^{\prime \prime}\right)+\mathrm{H}\left({ }^{2} \mathrm{~S}\right)$ & 121.13 & 119.46 & 120.26 \\
$\mathrm{OH}_{2} \mathrm{NCH}_{3}^{+}\left({ }^{2} \mathrm{~A}\right)+\mathrm{H}\left({ }^{2} \mathrm{~S}\right)$ & 149.02 & 144.49 & 145.71 \\
$\mathrm{OHNHCH}_{3}^{+}\left({ }^{2} \mathrm{~A}\right)+\mathrm{H}\left({ }^{2} \mathrm{~S}\right)$ & 115.13 & 112.36 & 112.85 \\
\hline
\end{tabular}

Notes.

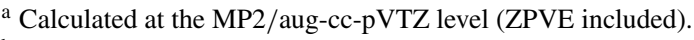

${ }^{\mathrm{b}}$ Calculated at the CCSD(T)/aug-cc-pVTZ//MP2/aug-cc-pVTZ level (ZPVE included).

${ }^{c}$ Calculated at the CCSD(T)/aug-cc-pVQZ//MP2/aug-cc-pVTZ level (ZPVE included).

\section{RESULTS AND DISCUSSION}

$$
\text { 3.1. } \mathrm{H}_{2} \mathrm{CO}+\mathrm{NH}_{4}^{+} \text {Reaction }
$$

The ion-molecule reaction between formaldehyde and ammonium cation has been proposed as a possible source of formamide in space (Halfen et al. 2011; Quan \& Herbst 2007). Both reactants are present in the interstellar medium (Synder et al. 1969; Cernicharo et al. 2013). This reaction is viable in space from a thermodynamic point of view according to the reaction enthalpy calculated in our previous work (Redondo et al. 2014). We found that the formation of protonated formamide is an exothermic process by $-3.06 \mathrm{kcal} \mathrm{mol}^{-1}$ at the $\operatorname{CCSD}(\mathrm{T}) / \mathrm{aug}$ cc-pVQZ//B3LYP/aug-cc-pVTZ level. However, to determine the possible role of this reaction in the formation of formamide, an exhaustive study of the potential energy surface is necessary. Before analyzing the potential energy surface, we have computed the reactions enthalpies for the formation of various products. These results are collected in Table 1 .

A possible product that we can obtain from the reaction of $\mathrm{NH}_{4}^{+}$and formaldehyde is protonated formamide. Protonation of formamide can take place at the oxygen atom or the nitrogen one, giving two different isomers: O-protonated formamide, $\mathrm{NH}_{2} \mathrm{CHOH}^{+}\left({ }^{1} \mathrm{~A}^{\prime}\right)$, and $\mathrm{N}$-protonated formamide, $\mathrm{NH}_{3} \mathrm{CHO}^{+}\left({ }^{1} \mathrm{~A}^{\prime}\right)$, respectively. From the results shown in Table 1 , we can see that only the process giving $\mathrm{O}$-protonated formamide, $\mathrm{NH}_{2} \mathrm{CHOH}^{+}\left({ }^{1} \mathrm{~A}^{\prime}\right)$, is exothermic $\left(\Delta H=-3.68 \mathrm{kcal} \mathrm{mol}^{-1}\right.$ at the $\operatorname{CCSD}(\mathrm{T}) /$ aug-cc-pVQZ level). Other possible products considered are ionized aminometanol, $\mathrm{NH}_{2} \mathrm{CH}_{2} \mathrm{OH}^{+}\left({ }^{2} \mathrm{~A}\right)$, and its isomer $\mathrm{NH}_{3} \mathrm{CH}_{2} \mathrm{O}^{+}\left({ }^{2} \mathrm{~A}^{\prime \prime}\right)$; both processes are endothermic by more than $90 \mathrm{kcal} \mathrm{mol}^{-1}$. Formation processes of isomers with $\mathrm{N}-\mathrm{O}-\mathrm{C}$ connectivity, namely, $\mathrm{NH}_{2} \mathrm{OCH}_{2}^{+}\left({ }^{1} \mathrm{~A}^{\prime}\right)$ and $\mathrm{NH}_{2} \mathrm{OCH}_{3}^{+}\left({ }^{2} \mathrm{~A}^{\prime \prime}\right)$, are clearly endothermic $(\Delta H=76.80$ and $120.26 \mathrm{kcal} \mathrm{mol}^{-1}$, respectively, at the $\operatorname{CCSD}(\mathrm{T}) /$ aug-cc-pVQZ level). We have also considered different compounds which have $\mathrm{O}-\mathrm{N}-\mathrm{C}$ connectivity, but formation of these species from the reaction of $\mathrm{NH}_{4}^{+}$with formaldehyde is clearly endothermic (see Table 1). Therefore, only the formation of O-protonated 


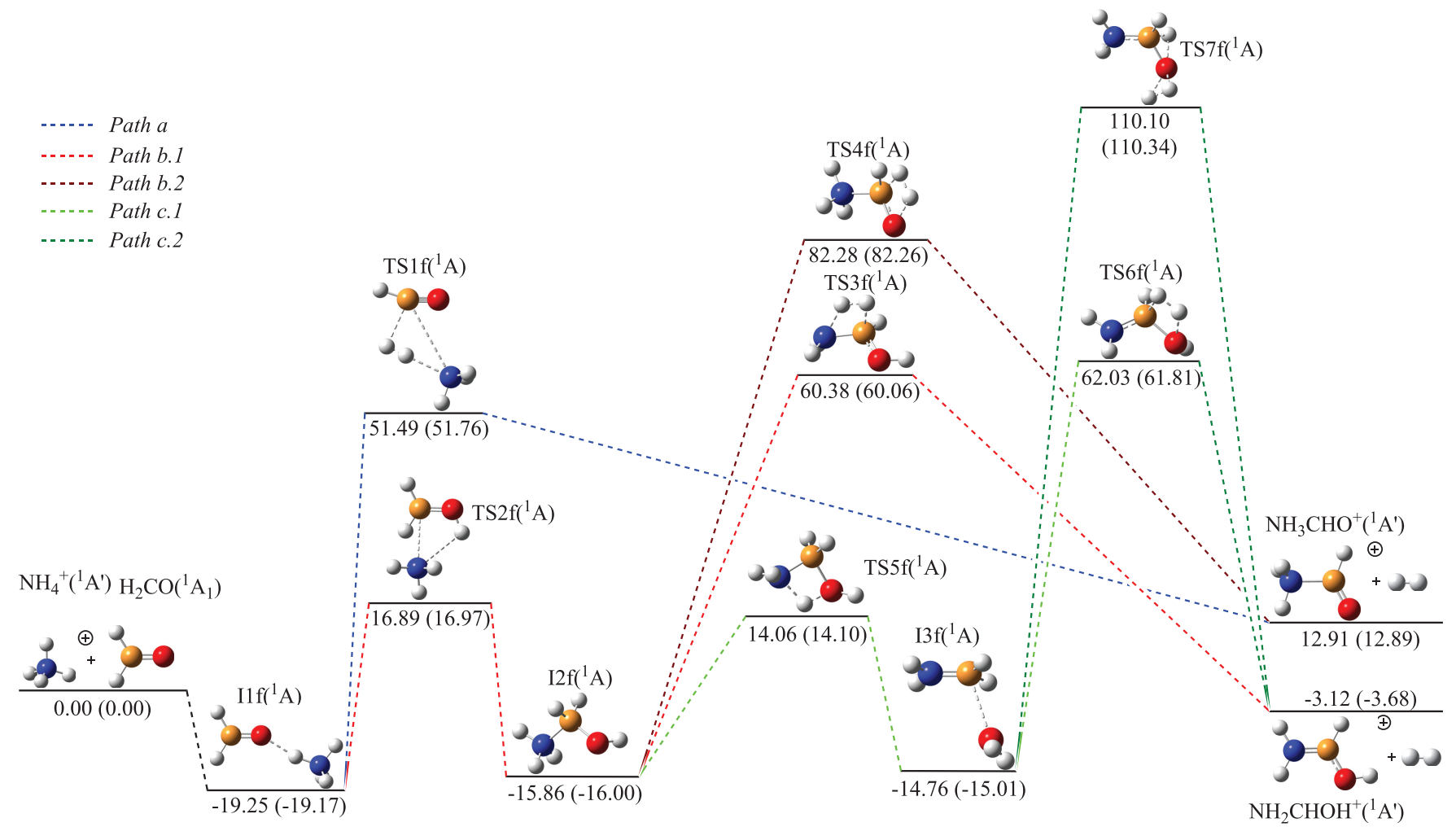

Figure 1. Energy profile, in kcal mol ${ }^{-1}$, for the reaction of $\mathrm{NH}_{4}^{+}$with $\mathrm{H}_{2} \mathrm{CO}$ at the CCSD(T)/aug-cc-pVTZ//MP2/aug-cc-pVTZ and CCSD(T)/aug-cc-pVQZ// MP2/aug-cc-pVTZ (in parentheses) levels. Zero-point vibrational energy differences are included.

(A color version of this figure is available in the online journal.)

formamide is an exothermic process. This product could give formamide upon a recombination dissociative reaction.

Finally, we can see in Table 1 that the results obtained at the MP2 level are relatively close to those computed at the $\operatorname{CCSD}(\mathrm{T})$ level. The differences found between energies calculated at the $\operatorname{CCSD}(\mathrm{T})$ level with the aug-cc-pVTZ and the aug-cc-pVQZ bases are less than $1 \mathrm{kcal} \mathrm{mol}^{-1}$.

Now, we will focus on the study of the potential energy surface in order to analyze if the formation of the exothermic product, $\mathrm{NH}_{2} \mathrm{CHOH}^{+}\left({ }^{1} \mathrm{~A}^{\prime}\right)$, is a barrier-free process and therefore viable in the interstellar medium. The relevant intermediate species and products, as well as the transition states of the reaction between formaldehyde and ammonium cation, are shown in Figure 1. This reaction takes place on the singlet potential surface, given the multiplicity of reactants $\left(\mathrm{H}_{2} \mathrm{CO}\left({ }^{1} \mathrm{~A}_{1}\right)\right.$ and $\left.\mathrm{NH}_{4}^{+}\left({ }^{1} \mathrm{~A}^{\prime}\right)\right)$. We denote intermediates and transition states for this reactions with $\operatorname{Inf}$ and $\operatorname{TS} n f(n=1,2, \ldots)$, respectively. As we can see in Figure 1, a similar energy profile is obtained at the $\operatorname{CCSD}(\mathrm{T})$ level with the aug-cc-pVTZ and aug-cc-pVQZ bases. The differences between the relative energies obtained with both bases are less than $0.5 \mathrm{kcal} \mathrm{mol}^{-1}$.

The reaction of ammonium cation with formaldehyde starts with the interaction between one of the hydrogen atoms of $\mathrm{NH}_{4}^{+}$with the carbonyl oxygen of formaldehyde resulting in the formation of an ion-molecule complex $\operatorname{I1f}\left({ }^{1} \mathrm{~A}^{\prime}\right)$. From this complex, five different evolution channels are possible. If IIf $\left({ }^{1} \mathrm{~A}^{\prime}\right)$ evolves through transition state $\operatorname{TS} 1 \mathrm{f}\left({ }^{1} \mathrm{~A}\right)$, we reach the less stable isomer of protonated formamide. This process corresponds to Path $a$ in Figure 1 and can be summarized as

$$
\begin{array}{cr}
\mathrm{NH}_{4}^{+}\left({ }^{1} \mathrm{~A}^{\prime}\right)+\mathrm{H}_{2} \mathrm{CO}\left({ }^{1} \mathrm{~A}_{1}\right) \rightarrow \operatorname{I1f}\left({ }^{1} \mathrm{~A}\right) & \rightarrow \operatorname{TS} 1 \mathrm{f}\left({ }^{1} \mathrm{~A}\right) \\
\rightarrow \mathrm{NH}_{3} \mathrm{CHO}^{+}\left({ }^{1} \mathrm{~A}^{\prime}\right)+\mathrm{H}_{2}\left({ }^{1} \sum_{\mathrm{g}}^{+}\right) & \text {Path } a
\end{array}
$$

In $\operatorname{TS} 1 \mathrm{f}\left({ }^{1} \mathrm{~A}\right)$, formation of the $\mathrm{C}-\mathrm{N}$ bond and $\mathrm{H}_{2}$ elimination take place simultaneously. This transition state is located at $51.76 \mathrm{kcal} \mathrm{mol}^{-1}$ above the reactants at the $\operatorname{CCSD}(\mathrm{T}) /$ aug-cc-pVQZ level. Therefore, the global process, endothermic and with a net activation energy, is not feasible under interstellar conditions.

Intermediate $\operatorname{I1f}\left({ }^{1} \mathrm{~A}\right)$ can also isomerize to $\mathrm{N}$-protonated aminomethanol, $\mathrm{NH}_{3} \mathrm{CH}_{2} \mathrm{OH}^{+}\left(\mathrm{I} 2 \mathrm{f}\left({ }^{1} \mathrm{~A}\right)\right)$. Transition state TS2f $\left({ }^{1} \mathrm{~A}\right)$ connects both intermediates. Once intermediate I2 $\left({ }^{1} \mathrm{~A}\right)$ is reached, elimination of molecular hydrogen through transition states $\operatorname{TS} 3 \mathrm{f}\left({ }^{1} \mathrm{~A}\right)$ and $\operatorname{TS} 4 \mathrm{f}\left({ }^{1} \mathrm{~A}\right)$ yields both isomers of protonated formamide, $\mathrm{NH}_{2} \mathrm{CHOH}^{+}\left({ }^{1} \mathrm{~A}^{\prime}\right)$ and $\mathrm{NH}_{3} \mathrm{CHO}^{+}\left({ }^{1} \mathrm{~A}^{\prime}\right)$, respectively (Paths b.1 and b.2, Figure 1):

$$
\begin{aligned}
& \operatorname{I1f}\left({ }^{1} \mathrm{~A}\right) \rightarrow \operatorname{TS} 2 \mathrm{f}\left({ }^{1} \mathrm{~A}\right) \rightarrow \operatorname{I2f}\left({ }^{1} \mathrm{~A}\right) \\
& \quad \rightarrow \begin{cases}\mathrm{TS} 3 \mathrm{f}\left({ }^{1} \mathrm{~A}\right) \rightarrow \mathrm{NH}_{2} \mathrm{CHOH}^{+}\left({ }^{1} \mathrm{~A}^{\prime}\right)+\mathrm{H}_{2}\left({ }^{1} \sum_{\mathrm{g}}^{+}\right) & \text {Path } b .1 \\
\operatorname{TS} 4 \mathrm{f}\left({ }^{1} \mathrm{~A}\right) \rightarrow \mathrm{NH}_{3} \mathrm{CHO}^{+}\left({ }^{1} \mathrm{~A}^{\prime}\right)+\mathrm{H}_{2}\left({ }^{1} \sum_{\mathrm{g}}^{+}\right) & \text {Path } b .2\end{cases}
\end{aligned}
$$

Path b.l leads to the formation of the most stable isomer of protonated formamide. This process, as we have previously commented, is exothermic, but the two transition states involved, $\operatorname{TS} 2 \mathrm{f}\left({ }^{1} \mathrm{~A}\right)$ and $\operatorname{TS} 3 \mathrm{f}\left({ }^{1} \mathrm{~A}\right)$, are located above the reactants $(16.97$ and $60.06 \mathrm{kcal} \mathrm{mol}^{-1}$ at the $\operatorname{CCSD}(\mathrm{T})$ aug-cc-pVQZ level, respectively), and therefore this channel is not viable under interstellar conditions. N-protonated aminometanol, I2f $\left({ }^{1} \mathrm{~A}\right)$, could isomerize to $\mathrm{O}$-protonated aminometanol $\left(\mathrm{NH}_{2} \mathrm{CH}_{2} \mathrm{OH}_{2}^{+}\left({ }^{1} \mathrm{~A}\right)\right.$, I3f $\left.\left({ }^{1} \mathrm{~A}\right)\right)$ through transition state $\operatorname{TS} 5 \mathrm{f}\left({ }^{1} \mathrm{~A}\right)$. Both isomers of protonated formamide, $\mathrm{NH}_{2} \mathrm{CHOH}^{+}\left({ }^{1} \mathrm{~A}^{\prime}\right)$ and $\mathrm{NH}_{3} \mathrm{CHO}^{+}\left({ }^{1} \mathrm{~A}^{\prime}\right)$, can be also reached from O-protonated aminometanol, $\operatorname{I3f}\left({ }^{1} \mathrm{~A}\right)$, by molecular hydrogen abstraction. These processes (Paths $c .1$ and 
Table 2

Reaction Enthalpies for the Gas-phase Reaction $\mathrm{CH}_{5}^{+}\left({ }^{1} \mathrm{~A}^{\prime}\right)+\mathrm{NH}_{2} \mathrm{CHO}\left({ }^{1} \mathrm{~A}^{\prime}\right)$ Calculated at $0 \mathrm{~K}$

\begin{tabular}{lccc}
\hline \hline Products & $\begin{array}{c}\Delta H^{\mathrm{a}} \\
\left(\mathrm{kcal} \mathrm{mol}^{-1}\right)\end{array}$ & $\begin{array}{c}\Delta H^{\mathrm{b}} \\
\left(\mathrm{kcal} \mathrm{Mol}^{-1}\right)\end{array}$ & $\begin{array}{c}\Delta H^{\mathrm{c}} \\
\left(\mathrm{kcal} \mathrm{mol}^{-1}\right)\end{array}$ \\
\hline $\mathrm{CH}_{3} \mathrm{CONH}_{3}^{+}\left({ }^{1} \mathrm{~A}^{\prime}\right)+\mathrm{H}_{2}\left({ }^{1} \Sigma_{\mathrm{g}}^{+}\right)$ & -55.30 & -56.35 & -55.80 \\
$\mathrm{c}-\mathrm{CH}_{3} \mathrm{COHNH}_{2}^{+}\left({ }^{1} \mathrm{~A}^{\prime}\right)+\mathrm{H}_{2}\left({ }^{1} \Sigma_{\mathrm{g}}^{+}\right)$ & -66.91 & -68.64 & -68.63 \\
$\mathrm{t}-\mathrm{CH}_{3} \mathrm{COHNH}_{2}^{+}\left({ }^{1} \mathrm{~A}^{\prime}\right)+\mathrm{H}_{2}\left({ }^{1} \Sigma_{\mathrm{g}}^{+}\right)$ & -69.63 & -71.32 & -71.33 \\
$\mathrm{CH}_{3} \mathrm{NH}_{2} \mathrm{CHO}^{+}\left({ }^{1} \mathrm{~A}^{\prime}\right)+\mathrm{H}_{2}\left({ }^{1} \Sigma_{\mathrm{g}}^{+}\right)$ & -41.32 & -43.26 & \\
$\mathrm{CH}_{3} \mathrm{NHCHOH}^{+}\left({ }^{1} \mathrm{~A}^{\prime}\right)+\mathrm{H}_{2}\left({ }^{1} \Sigma_{\mathrm{g}}^{+}\right)$ & -56.96 & -58.99 & \\
$\mathrm{CH}_{3} \mathrm{CNHOH}_{2}^{+}\left({ }^{1} \mathrm{~A}\right)+\mathrm{H}_{2}\left({ }^{1} \Sigma_{\mathrm{g}}^{+}\right)$ & -26.00 & -27.68 & \\
$\mathrm{NH}_{3} \mathrm{CH}_{2} \mathrm{COH}^{+}\left({ }^{1} \mathrm{~A}^{\prime}\right)+\mathrm{H}_{2}\left({ }^{1} \Sigma_{\mathrm{g}}^{+}\right)$ & -49.59 & -51.33 & \\
$\mathrm{c}-\mathrm{NH}_{2} \mathrm{CH}_{2} \mathrm{CHOH}^{+}\left({ }^{1} \mathrm{~A}\right)+\mathrm{H}_{2}\left({ }^{1} \Sigma_{\mathrm{g}}^{+}\right)$ & -21.28 & -24.25 & \\
$\mathrm{t}-\mathrm{NH}_{2} \mathrm{CH}_{2} \mathrm{CHOH}^{+}\left({ }^{1} \mathrm{~A}\right)+\mathrm{H}_{2}\left({ }^{1} \Sigma_{\mathrm{g}}^{+}\right)$ & -34.54 & -35.62 & \\
$\mathrm{NH}_{2} \mathrm{CHCH}_{2} \mathrm{OH}^{+}\left({ }^{1} \mathrm{~A}\right)+\mathrm{H}_{2}\left({ }^{1} \Sigma_{\mathrm{g}}^{+}\right)$ & -41.10 & -44.35 & \\
$\mathrm{CH}_{3} \mathrm{COHNH}_{3}^{+}\left({ }^{2} \mathrm{~A}\right)+\mathrm{H}\left({ }^{2} \mathrm{~S}\right)$ & 25.49 & 24.50 & \\
$\left.\mathrm{NH}_{3} \mathrm{CH}_{2} \mathrm{CHOH}^{+}\left({ }^{2} \mathrm{~A}\right)+\mathrm{H}^{2} \mathrm{~S}\right)$ & 24.86 & 23.59 & \\
$\left.\mathrm{CH}_{3} \mathrm{CHNH}_{2} \mathrm{OH}^{+}\left({ }^{2} \mathrm{~A}\right)+\mathrm{H}^{2} \mathrm{~S}\right)$ & 41.40 & 37.18 & \\
$\left.\mathrm{NH}_{2} \mathrm{CH}_{2} \mathrm{CH}_{2} \mathrm{OH}^{+}\left({ }^{2} \mathrm{~A}\right)+\mathrm{H}^{2} \mathrm{~S}\right)$ & 41.44 & 37.48 & \\
\hline
\end{tabular}

Notes.

${ }^{a}$ Calculated at the MP2/aug-cc-pVTZ level (ZPVE included).

${ }^{b}$ Calculated at the CCSD(T)/aug-cc-pVTZ//MP2/aug-cc-pVTZ level (ZPVE included).

${ }^{c}$ Calculated at the CCSD(T)/aug-cc-pVQZ//MP2/aug-cc-pVTZ level (ZPVE included).

c. 2 in Figure 1) can be summarized as

$$
\begin{aligned}
& \mathrm{I} 2 \mathrm{f}\left({ }^{1} \mathrm{~A}\right) \rightarrow \operatorname{TS} 5 \mathrm{f}\left({ }^{1} \mathrm{~A}\right) \rightarrow \operatorname{I3f}\left({ }^{1} \mathrm{~A}\right) \\
& \quad \rightarrow \begin{cases}\mathrm{TS} 6 \mathrm{f}\left({ }^{1} \mathrm{~A}\right) \rightarrow \mathrm{NH}_{2} \mathrm{CHOH}^{+}\left({ }^{1} \mathrm{~A}^{\prime}\right)+\mathrm{H}_{2}\left({ }^{1} \sum_{\mathrm{g}}^{+}\right) & \text {Path c.1 } \\
\operatorname{TS} 7 f\left({ }^{1} \mathrm{~A}\right) \rightarrow \mathrm{NH}_{3} \mathrm{CHO}^{+}\left({ }^{1} \mathrm{~A}^{\prime}\right)+\mathrm{H}_{2}\left({ }^{1} \sum_{\mathrm{g}}^{+}\right) & \text {Path c. } 2\end{cases}
\end{aligned}
$$

We can see in Figure 1 that these processes have net activation barriers since transition states involved in these paths, $\operatorname{TS} 5 \mathrm{f}\left({ }^{1} \mathrm{~A}\right)$, TS6f $\left({ }^{1} \mathrm{~A}\right)$, and $\operatorname{TS} 7 \mathrm{f}\left({ }^{1} \mathrm{~A}\right)$, are clearly located above the reactants $\left(14.10,61.81\right.$, and $110.34 \mathrm{kcal} \mathrm{mol}^{-1}$ at the $\operatorname{CCSD}(\mathrm{T}) /$ aug-ccpVQZ level, respectively).

Summarizing, the analysis of the potential energy surface of the reaction between ammonium cation and formaldehyde shows that formation of O-protonated formamide $\left(\mathrm{NH}_{2} \mathrm{CHOH}^{+}\left({ }^{1} \mathrm{~A}^{\prime}\right)\right)$, in spite of being an exothermic process, is not viable under interstellar conditions because the different paths leading to this isomer present net activation energies. Therefore, this reaction cannot be considered as a possible source of formamide in space. If we take into account our previous results for the gas-phase reactions of ionized, protonated, and neutral hydroxylamine with formaldehyde (Redondo et al. 2014) where formation of formamide precursors is not viable from these reactions, we can conclude that other alternative routes, such as reactions on ice surfaces, should be investigated.

\section{$3.2 \mathrm{CH}_{5}^{+}+\mathrm{NH}_{2} \mathrm{COH}$ Reaction}

In this section, we will discuss the feasibility of acetamide formation under interstellar conditions from the reaction of methanium with formamide. It should be pointed out that $\mathrm{CH}_{5}^{+}$has not been detected in space, but it is considered as reactant in different interstellar models. First, we analyze the reaction enthalpies for different products that can be obtained from these reactants. Reaction enthalpies are shown in Table 2. Taking into account that reaction enthalpies calculated in the previous section at the CCSD(T)/aug-cc-pVTZ level are close to those computed at the $\operatorname{CCSD}(\mathrm{T}) /$ aug-cc-pVQZ one for these systems, energy calculations are only carried out at the CCSD(T)/aug-cc-pVTZ level. As possible products, we have taken into account systems resulting from hydrogen molecule abstraction; $\left[\mathrm{C}_{2} \mathrm{H}_{6} \mathrm{NO}\right]^{+}+\mathrm{H}_{2} \cdot\left[\mathrm{C}_{2} \mathrm{H}_{6} \mathrm{NO}\right]^{+}$isomers are obtained from protonation of neutral $\left[\mathrm{C}_{2} \mathrm{H}_{5} \mathrm{NO}\right]$ systems. In a theoretical study, Lattelais et al. (2010) show that the two $\left[\mathrm{C}_{2} \mathrm{H}_{5} \mathrm{NO}\right.$ ] isomers of lower energy contain a peptide bond. The most stable one is acetamide $\mathrm{CH}_{3} \mathrm{CONH}_{2}$, and the next one is $\mathrm{N}$ methyl formamide, $\mathrm{CH}_{3} \mathrm{NHCHO}$. The enolic form of acetamide, $\mathrm{CH}_{3} \mathrm{COHNH}$, is the third in stability. We will focus on the protonated form of these isomers which present a $\mathrm{N}-\mathrm{C}-\mathrm{O}$ connectivity and could be precursors of molecules with a peptide bond. In addition, due to its prebiotic interest, we have also considered the protonation products of amino acetaldehyde, $\mathrm{NH}_{2} \mathrm{CH}_{2} \mathrm{COH}$, a possible precursor of glycine.

The first product that we have considered is protonated acetamide. Protonation of acetamide can take place on the nitrogen atom or on the oxygen one giving two isomers, $\mathrm{N}$-protonated acetamide $\left(\mathrm{CH}_{3} \mathrm{CONH}_{3}^{+}\left({ }^{1} \mathrm{~A}^{\prime}\right)\right)$ and O-protonated acetamide $\left(\mathrm{CH}_{3} \mathrm{COHNH}_{2}^{+}\left({ }^{1} \mathrm{~A}^{\prime}\right)\right)$, respectively. Formation of $\mathrm{N}$ protonated acetamide $\left(\mathrm{CH}_{3} \mathrm{CONH}_{3}^{+}\left({ }^{1} \mathrm{~A}^{\prime}\right)\right)$ is an exothermic process $\left(\Delta H=-56.35 \mathrm{kcal} \mathrm{mol}^{-1}\right.$ at the $\operatorname{CCSD}(\mathrm{T}) /$ aug-cc-pVTZ level). When protonation takes place on the oxygen atom, two different conformers are localized depending on the relative orientation of the proton with respect to the $\mathrm{NH}_{2}$ unit, namely, cis-O-protonated acetamide $\left(\mathrm{c}-\mathrm{CH}_{3} \mathrm{COHNH}_{2}^{+}\left({ }^{1} \mathrm{~A}^{\prime}\right)\right)$ and trans$\mathrm{O}$-protonated acetamide $\left(\mathrm{t}-\mathrm{CH}_{3} \mathrm{COHNH}_{2}^{+}\left({ }^{1} \mathrm{~A}^{\prime}\right)\right)$. The formation processes of these conformers of O-protonated acetamide are exothermic $\left(\Delta H=-68.64\right.$ and $-71.32 \mathrm{kcal} \mathrm{mol}^{-1}$ at the CCSD(T)/aug-cc-pVTZ level, respectively). In order to check our energetic predictions, we have computed the reaction enthalpies for protonated acetamide at the $\operatorname{CCSD}(\mathrm{T}) /$ aug-ccpVQZ level, and as we can see in Table 2, the results are, as in the reaction between protonated ammonia and formaldehyde, close to those obtained with the aug-cc-pVTZ basis set.

Both $\mathrm{N}$-protonated $\left(\mathrm{CH}_{3} \mathrm{NH}_{2} \mathrm{CHO}^{+}\left({ }^{1} \mathrm{~A}^{\prime}\right)\right)$ and O-protonated $\left(\mathrm{CH}_{3} \mathrm{NHCHOH}^{+}\left({ }^{1} \mathrm{~A}^{\prime}\right)\right) \mathrm{N}$-metyl formamide are exothermic products $\left(\Delta \mathrm{H}=-43.26\right.$ and $-58.99 \mathrm{kcal} \mathrm{mol}^{-1}$ at the $\operatorname{CCSD}(\mathrm{T}) /$ aug-cc-pVTZ level, respectively). As in the case of acetamide, protonation on the oxygen atom is more favorable than protonation on the nitrogen one. Formation of the $\mathrm{CH}_{3} \mathrm{CNHOH}_{2}^{+}\left({ }^{1} \mathrm{~A}\right)$ isomer is also an exothermic process. This isomer can be considered as resulting from the oxygen atom protonation of the enolic form of acetamide. When the protonation of $\mathrm{CH}_{3} \mathrm{COHNH}$ takes place on the nitrogen atom, we obtain O-protonated acetamide, $\mathrm{CH}_{3} \mathrm{COHNH}_{2}^{+}\left({ }^{1} \mathrm{~A}^{\prime}\right)$. Protonation of amino acetaldehyde, on either an oxygen atom or a nitrogen one, are clearly exothermic processes. It should be noted that two different conformers are considered for the product protonated on the oxygen atom that corresponds to different orientations of the $\mathrm{OH}$ group with respect to the $\mathrm{NH}_{2}$ one. Finally, we have also included the isomer corresponding to the enolic form of protonated amino acetaldehyde, $\mathrm{NH}_{2} \mathrm{CHCH}_{2} \mathrm{OH}^{+}\left({ }^{1} \mathrm{~A}\right)$, which is clearly an exothermic product $\left(\Delta H=-44.35 \mathrm{kcal} \mathrm{mol}^{-1}\right.$ at the $\operatorname{CCSD}(\mathrm{T}) /$ aug-cc-pVTZ level). All the $\left[\mathrm{C}_{2} \mathrm{H}_{6} \mathrm{NO}\right]^{+}$isomers considered will be reached from the reaction of $\mathrm{CH}_{5}^{+}$with formamide.

Formation of products obtained when one hydrogen atom abstraction takes place, $\left[\mathrm{C}_{2} \mathrm{H}_{7} \mathrm{NO}\right]^{+}+\mathrm{H}$, is also considered. Different isomers of the $\left[\mathrm{C}_{2} \mathrm{H}_{7} \mathrm{NO}^{+}\right.$system are taken into account, namely, $\mathrm{CH}_{3} \mathrm{COHNH}_{3}^{+}\left({ }^{2} \mathrm{~A}\right), \mathrm{NH}_{3} \mathrm{CH}_{2} \mathrm{CHOH}^{+}\left({ }^{2} \mathrm{~A}\right)$, 


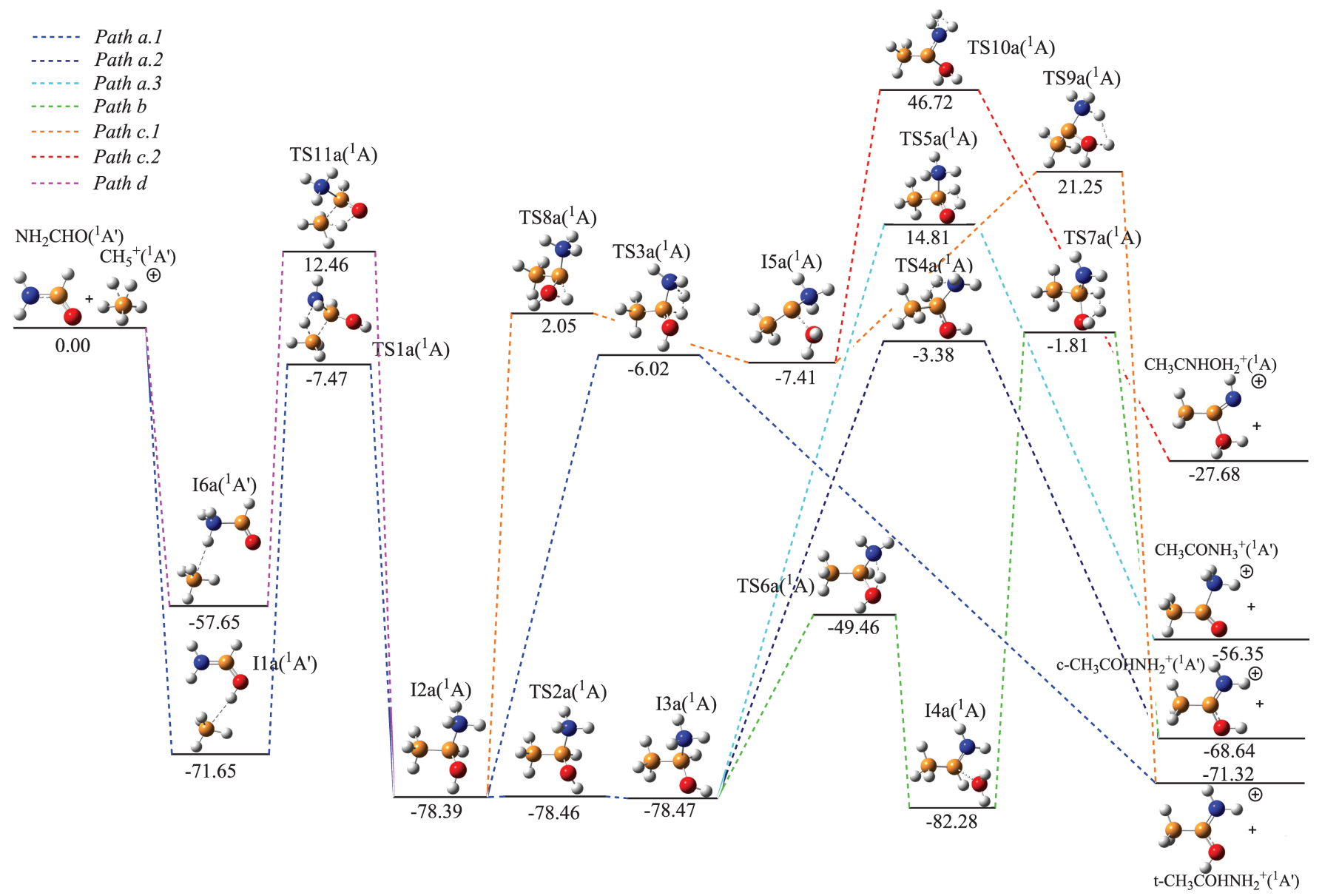

Figure 2. Energy profile (part I), in $\mathrm{kcal} \mathrm{mol}^{-1}$, for the reaction of $\mathrm{CH}_{5}^{+}$with $\mathrm{NH}_{2} \mathrm{CHO}$ at the CCSD(T)/aug-cc-pVTZ//MP2/aug-cc-pVTZ level. Zero-point vibrational energy differences are included.

(A color version of this figure is available in the online journal.)

$\mathrm{CH}_{3} \mathrm{CHNH}_{2} \mathrm{OH}^{+}\left({ }^{2} \mathrm{~A}\right)$, and $\mathrm{NH}_{2} \mathrm{CH}_{2} \mathrm{CH}_{2} \mathrm{OH}^{+}\left({ }^{2} \mathrm{~A}\right)$, but as we can see in Table 2, all the processes are clearly endothermic, and therefore they are not viable in the interstellar medium.

We have localized different intermediates and transition states on the singlet $\left[\mathrm{C}_{2} \mathrm{H}_{8} \mathrm{NO}\right]^{+}$surface in order to find reliable routes leading to the formation of exothermic products. To simplify the results, the global profile for this reaction is split into two figures (Figures 2 and 3). Paths leading to the two conformers of O-protonated acetamide and N-protonated acetamide and to the formation of the oxygen atom protonated of the enolic form of acetamide are collected in Figure 2. In addition, Figure 3 shows channels leading to the formation of protonated $\mathrm{N}$ methyl formamide and amino acetaldehyde on both oxygen and nitrogen atoms. Considering that the relative energies calculated with the aug-cc-PVTZ basis set and the aug-cc-pVQZ one at the $\operatorname{CCSD}(\mathrm{T})$ level are found close for the previous reaction and given the size of this system, we have just calculated relative energies at the CCSD(T)/aug-cc-pVTZ level. Intermediates and transition states for this reaction are denoted by Ina and TSna $(n=1,2, \ldots)$, respectively.

Figure 2 shows that the reaction of $\mathrm{CH}_{5}^{+}$with formamide starts with the proton transfer from $\mathrm{CH}_{5}^{+}$to the carbonyl oxygen of formamide, giving the intermediate I $1 \mathrm{a}\left({ }^{1} \mathrm{~A}\right)$. Then formation of a $\mathrm{C}-\mathrm{C}$ bond and the simultaneous hydrogen atom transfer from carbon to nitrogen take place through transition state $\mathrm{TS} 1 \mathrm{a}\left({ }^{1} \mathrm{~A}\right)$ producing a second intermediate, $\mathrm{I} 2\left({ }^{1} \mathrm{~A}\right)$. This species can isomerize into $\mathrm{I} 3 \mathrm{a}\left({ }^{1} \mathrm{~A}\right)$, which only differs from $\mathrm{I} 2\left({ }^{1} \mathrm{~A}\right)$ in the relative orientation of the $\mathrm{O}-\mathrm{H}$ bond. The transition state involved in this isomerization TS2a $\left({ }^{1} \mathrm{~A}\right)$ is located at the MP2 level, but it is found to disappear when correlation energy is included at the $\operatorname{CCSD}(\mathrm{T})$ level; therefore, isomerization of I2a $\left({ }^{1} \mathrm{~A}\right)$ into I3a $\left({ }^{1} \mathrm{~A}\right)$ seems to be a spontaneous process.

$$
\begin{aligned}
& \mathrm{CH}_{5}^{+}\left({ }^{1} \mathrm{~A}^{\prime}\right)+\mathrm{NH}_{2} \mathrm{CHO}\left({ }^{1} \mathrm{~A}^{\prime}\right) \rightarrow \mathrm{I} 1 \mathrm{a}\left({ }^{1} \mathrm{~A}\right) \rightarrow \mathrm{TS} 1 \mathrm{a}\left({ }^{1} \mathrm{~A}\right) \\
& \quad \rightarrow \mathrm{I} 2 \mathrm{a}\left({ }^{1} \mathrm{~A}\right) \rightarrow \mathrm{TS} 2 \mathrm{a}\left({ }^{1} \mathrm{~A}\right) \rightarrow \mathrm{I} 3 \mathrm{a}\left({ }^{1} \mathrm{~A}\right)
\end{aligned}
$$

Once $\mathrm{I} 2 \mathrm{a}\left({ }^{1} \mathrm{~A}\right)$ or $\mathrm{I} 3 \mathrm{a}\left({ }^{1} \mathrm{~A}\right)$ are reached, hydrogen molecule elimination leads to O-protonated acetamide, involving transition states TS3a $\left({ }^{1} \mathrm{~A}\right)$ or TS4a $\left({ }^{1} \mathrm{~A}\right)$, or $\mathrm{N}$-protonated acetamide, where transition state TS5a $\left({ }^{1} \mathrm{~A}\right)$ is implicated. These processes (Paths a.1, a.2, and a.3 in Figure 2) can be summarized as

$$
\begin{aligned}
& \mathrm{I} 2 \mathrm{a}\left({ }^{1} \mathrm{~A}\right) \rightarrow \mathrm{TS} 3 \mathrm{a}\left({ }^{1} \mathrm{~A}\right) \rightarrow \mathrm{t}-\mathrm{CH}_{3} \mathrm{COHNH}_{2}^{+}\left({ }^{1} \mathrm{~A}^{\prime}\right)+\mathrm{H}_{2}\left({ }^{1} \Sigma_{\mathrm{g}}^{+}\right) \\
& \text {Path a.l } \\
& \mathrm{I} 3 \mathrm{a}\left({ }^{1} \mathrm{~A}\right) \rightarrow\left\{\begin{array}{c}
\mathrm{TS} 4 \mathrm{a}\left({ }^{1} \mathrm{~A}\right) \rightarrow \mathrm{c}-\mathrm{CH}_{3} \mathrm{COHNH}_{2}^{+}\left({ }^{1} \mathrm{~A}^{\prime}\right)+\mathrm{H}_{2}\left({ }^{1} \Sigma_{\mathrm{g}}^{+}\right) \\
\text {Path a. } 2 \\
\mathrm{TS} 5 \mathrm{a}\left({ }^{1} \mathrm{~A}\right) \rightarrow \mathrm{CH}_{3} \mathrm{CONH}_{3}^{+}\left({ }^{1} \mathrm{~A}^{\prime}\right)+\mathrm{H}_{2}\left({ }^{1} \Sigma_{\mathrm{g}}^{+}\right) \\
\text {Path a. } 3
\end{array}\right.
\end{aligned}
$$

Path a.1 leads to the formation of trans-O-protonated acetamide, an exothermic $\left(\Delta H=-71.32 \mathrm{kcal} \mathrm{mol}^{-1}\right.$ at the $\operatorname{CCSD}(\mathrm{T}) /$ aug-cc-pVTZ level) and barrier-free process. The transition states found along this path, $\operatorname{TS} 1 \mathrm{a}\left({ }^{1} \mathrm{~A}\right)$, and TS3a $\left({ }^{1} \mathrm{~A}\right)$, are located below the reactants $(\Delta E=-7.47$ and 


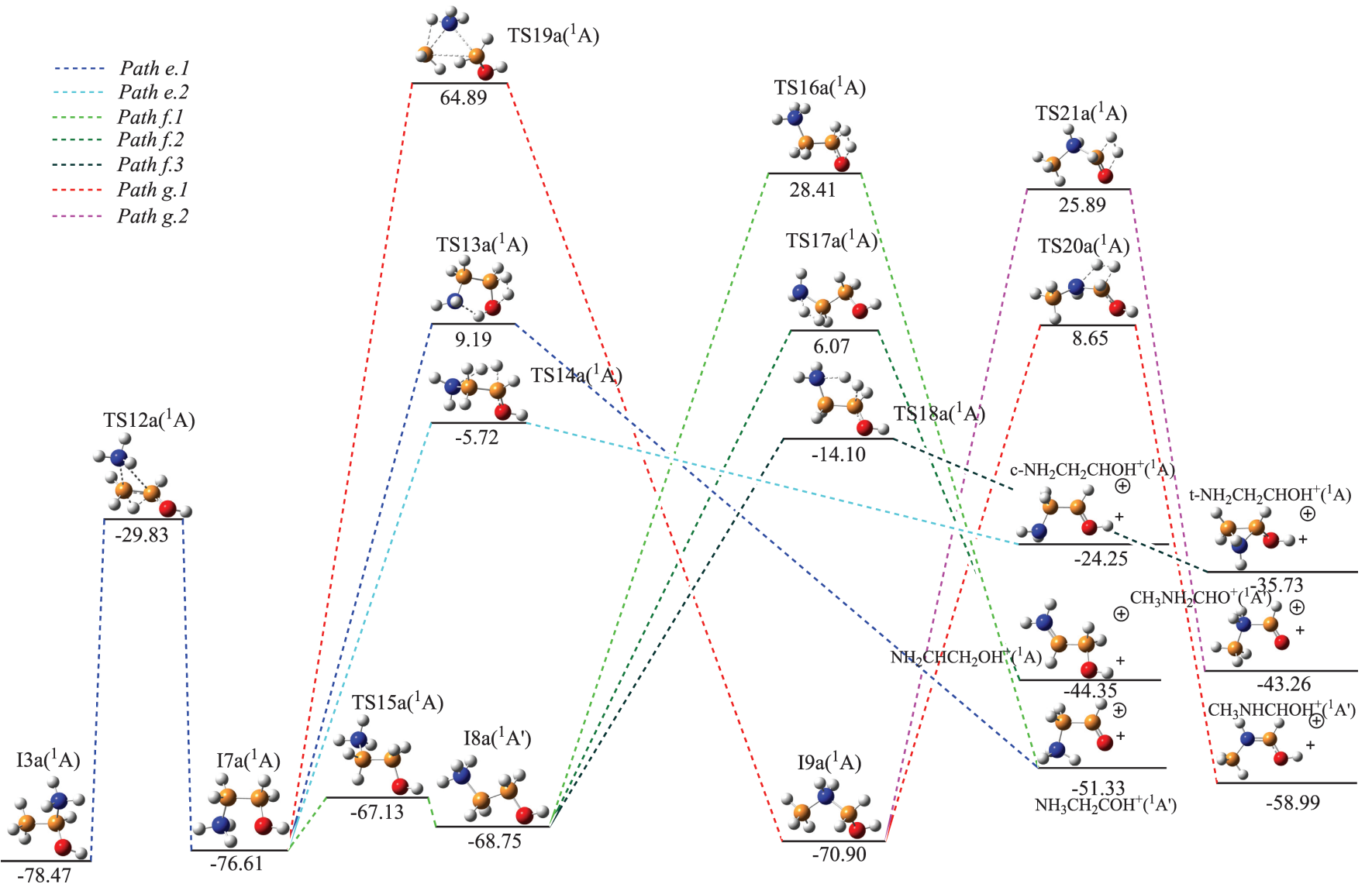

Figure 3. Energy profile (part II), in kcal mol${ }^{-1}$, for the reaction of $\mathrm{CH}_{5}^{+}$with $\mathrm{NH}_{2} \mathrm{CHO}$ at the $\mathrm{CCSD}(\mathrm{T}) /$ aug-cc-pVTZ//MP2/aug-cc-pVTZ level. Zero-point vibrational energy differences are included.

(A color version of this figure is available in the online journal.)

$-6.02 \mathrm{kcal} \mathrm{mol}^{-1}$ at the CCSD(T)/aug-cc-pVTZ level, respectively). From I3a $\left({ }^{1} \mathrm{~A}\right)$, one can reach cis-O-protonated acetamide through transition state $\mathrm{TS} 4 \mathrm{a}\left({ }^{1} \mathrm{~A}\right)$ (Path a.2). The global process is also exothermic $\left(\Delta H=-68.64 \mathrm{kcal} \mathrm{mol}^{-1}\right.$ at the $\mathrm{CCSD}(\mathrm{T}) /$ aug-cc-pVTZ level) and barrier free $\left(\mathrm{TS} 4 \mathrm{a}\left({ }^{1} \mathrm{~A}\right)\right.$ is located $3.38 \mathrm{kcal} \mathrm{mol}^{-1}$ below the reactants at the $\operatorname{CCSD}(\mathrm{T}) /$ augcc-pVTZ level). Therefore, the reaction between $\mathrm{CH}_{5}^{+}$and formamide can yield both conformers of O-protonated acetamide under interstellar conditions. It should be pointed out that both conformers could coexist in space because the interconversion process presents a net activation barrier of $7.91 \mathrm{kcal} \mathrm{mol}^{-1}$ evaluated at the $\operatorname{CCSD}(\mathrm{T}) /$ aug-cc-pVTZ level. However, formation of the N-protonated acetamide through Path a.3 is not viable under interstellar conditions because involves transition state TS5a $\left({ }^{1} \mathrm{~A}\right)$ which is clearly located above the reactants (14.81 kcal mol ${ }^{-1}$ at the $\operatorname{CCSD}(\mathrm{T}) /$ aug-cc-pVTZ level).

An alternative channel to obtain O-protonated acetamide is Path $b$ (Figure 2), where a hydrogen transfer from the $\mathrm{NH}_{3}$ group to the oxygen atom in $\mathrm{I} 3 \mathrm{a}\left({ }^{1} \mathrm{~A}\right)$ leads to $\mathrm{I} 4 \mathrm{a}\left({ }^{1} \mathrm{~A}\right)$. Once this intermediate is formed, $\mathrm{H}_{2}$ elimination leads to Oprotonated acetamide. In this process, TS6a $\left({ }^{1} \mathrm{~A}\right)$ and TS7a $\left({ }^{1} \mathrm{~A}\right)$ are implicated, both transition states are located below the reactants $\left(-49.46\right.$ and $-1.81 \mathrm{kcal} \mathrm{mol}^{-1}$ at the $\operatorname{CCSD}(\mathrm{T}) / \mathrm{aug}$ cc-pVTZ level, respectively). Therefore, Path $b$ is an alternative viable channel to obtain the cis conformer of O-protonated acetamide in space:

$$
\begin{aligned}
& \mathrm{I} 3 \mathrm{a}\left({ }^{1} \mathrm{~A}\right) \rightarrow \mathrm{TS} 6 \mathrm{a}\left({ }^{1} \mathrm{~A}\right) \rightarrow \mathrm{I} 4 \mathrm{a}\left({ }^{1} \mathrm{~A}\right) \rightarrow \mathrm{TS} 7 \mathrm{a}\left({ }^{1} \mathrm{~A}\right) \\
& \quad \rightarrow \mathrm{CH}_{3} \mathrm{COHNH}_{2}^{+}\left({ }^{1} \mathrm{~A}^{\prime}\right)+\mathrm{H}_{2}\left({ }^{1} \Sigma_{\mathrm{g}}^{+}\right)
\end{aligned}
$$

Path $b$
From I $2 \mathrm{a}\left({ }^{1} \mathrm{~A}\right)$, we can also reach the trans conformer of O-protonated acetamide following Path c.1:

$$
\begin{aligned}
& \mathrm{I} 2 \mathrm{a}\left({ }^{1} \mathrm{~A}\right) \rightarrow \mathrm{TS} 8 \mathrm{a}\left({ }^{1} \mathrm{~A}\right) \rightarrow \mathrm{I} 5 \mathrm{a}\left({ }^{1} \mathrm{~A}\right) \rightarrow \mathrm{TS} 9 \mathrm{a}\left({ }^{1} \mathrm{~A}\right) \\
& \rightarrow \mathrm{t}-\mathrm{CH}_{3} \mathrm{COHNH}_{2}^{+}\left({ }^{1} \mathrm{~A}^{\prime}\right)+\mathrm{H}_{2}\left({ }^{1} \Sigma_{\mathrm{g}}^{+}\right)
\end{aligned}
$$

Path c.1

Intermediate $\mathrm{I} 5 \mathrm{a}\left({ }^{1} \mathrm{~A}\right)$ is obtained from $\mathrm{I} 2 \mathrm{a}\left({ }^{1} \mathrm{~A}\right)$ through transition state $\mathrm{TS} 8 \mathrm{a}\left({ }^{1} \mathrm{~A}\right)$, where a hydrogen atom migration takes place from the central carbon atom to the oxygen one. Then hydrogen molecule abstraction gives a trans conformer of Oprotonated acetamide. Transition states involved in this process, TS8a $\left({ }^{1} \mathrm{~A}\right)$ and $\mathrm{TS} 9 \mathrm{a}\left({ }^{1} \mathrm{~A}\right)$, are located above the reactants ( 2.05 and $21.25 \mathrm{kcal} \mathrm{mol}^{-1}$ at the CCSD(T)/aug-cc-pVTZ level, respectively). Thus, path c.l is not viable under interstellar conditions because it presents a net activation barrier. Isomer $\mathrm{CH}_{3} \mathrm{CNHOH}_{2}^{+}\left({ }^{1} \mathrm{~A}\right)$ can also be reached from I5a $\left({ }^{1} \mathrm{~A}\right)$ when molecular hydrogen is eliminated from the $\mathrm{NH}_{3}$ group in TS10a $\left({ }^{1} \mathrm{~A}\right.$ ) (located $46.72 \mathrm{kcal} \mathrm{mol}^{-1}$ above the reactants at the CCSD(T)/aug-cc-pVTZ level). Therefore, formation of the oxygen atom protonated of the enolic form of acetamide seems not viable under interstellar conditions:

$$
\begin{aligned}
& \mathrm{I} 5 \mathrm{a}\left({ }^{1} \mathrm{~A}\right) \rightarrow \mathrm{TS} 10 \mathrm{a}\left({ }^{1} \mathrm{~A}\right) \rightarrow \mathrm{CH}_{3} \mathrm{CNHOH}_{2}^{+}\left({ }^{1} \mathrm{~A}\right) \\
& \quad+\mathrm{H}_{2}\left({ }^{1} \Sigma_{\mathrm{g}}^{+}\right)
\end{aligned}
$$

Path c.2

Intermediate $\mathrm{I} 6 \mathrm{a}\left({ }^{1} \mathrm{~A}\right)$ can be reached directly from reactants when proton transfer takes place from $\mathrm{CH}_{5}^{+}$to the nitrogen atom of formamide. This intermediate evolves through transition state TS1 $1 \mathrm{a}\left({ }^{1} \mathrm{~A}\right)$ to intermediate $\mathrm{I} 2 \mathrm{a}\left({ }^{1} \mathrm{~A}\right)($ Path $d$, Figure 2$)$. 
$\mathrm{TS} 11 \mathrm{a}\left({ }^{1} \mathrm{~A}\right)$ involves the formation of a $\mathrm{C}-\mathrm{C}$ bond and the hydrogen atom transfer from $\mathrm{CH}_{4}$ group to oxygen atom. However, in this case, TS $11 \mathrm{a}\left({ }^{1} \mathrm{~A}\right)$ is located $12.46 \mathrm{kcal} \mathrm{mol}^{-1}$ above the reactants at the CCSD(T)/aug-cc-pVTZ level, making the evolution of intermediate I6a $\left({ }^{1} \mathrm{~A}\right)$ not viable under interstellar conditions. It should be pointed out that the initial formation of intermediate $\mathrm{I} 1 \mathrm{a}\left({ }^{1} \mathrm{~A}\right)$ is more favorable than $\mathrm{I} 6 \mathrm{a}\left({ }^{1} \mathrm{~A}\right)$ by $14 \mathrm{kcal} \mathrm{mol}^{-1}$ at the CCSD(T)/aug-cc-pVTZ level.

Different channels leading to the formation of protonated $\mathrm{N}$-methyl formamide and amino acetaldehyde on both oxygen and nitrogen atoms (exothermic processes) are also located and collected in Figure 3. All paths start from intermediate $\mathrm{I} 3 \mathrm{a}\left({ }^{1} \mathrm{~A}\right)$, which, as we have previously mentioned, can be reached from the reaction of $\mathrm{CH}_{5}^{+}$with formamide under interstellar conditions (see Figure 2).

As one can see in Figure 3, the evolution of intermediate $\mathrm{I} 3 \mathrm{a}\left({ }^{1} \mathrm{~A}\right)$ starts by its isomerization into $\mathrm{I} 7 \mathrm{a}\left({ }^{1} \mathrm{~A}\right)$. This step involves transition state $\operatorname{TS} 12 \mathrm{a}\left({ }^{1} \mathrm{~A}\right)$, where the $\mathrm{NH}_{3}$ group migration from central carbon to the terminal one and simultaneous $\mathrm{H}$ migration in the opposite direction take place. Transition state $\operatorname{TS} 12 \mathrm{a}\left({ }^{1} \mathrm{~A}\right)$ is clearly located below the reactants $\left(-29.83 \mathrm{kcal} \mathrm{mol}^{-1}\right.$ at the CCSD(T)/aug-cc-pVTZ level), and therefore formation of intermediate $\mathrm{I} 7 \mathrm{a}\left({ }^{1} \mathrm{~A}\right)$ is a feasible process in space. Then, molecular hydrogen elimination can take place through transition state $\operatorname{TS} 13 \mathrm{a}\left({ }^{1} \mathrm{~A}\right)$ or $\mathrm{TS} 14 \mathrm{a}\left({ }^{1} \mathrm{~A}\right)$ giving $\mathrm{N}$ - or O-protonated amino acetaldehyde (cis conformer), respectively:

$$
\begin{aligned}
& \mathrm{I} 3 \mathrm{a}\left({ }^{1} \mathrm{~A}\right) \rightarrow \mathrm{TS} 12 \mathrm{a}\left({ }^{1} \mathrm{~A}\right) \rightarrow \mathrm{I} 7 \mathrm{a}\left({ }^{1} \mathrm{~A}\right) \\
& \quad \rightarrow\left\{\begin{array}{r}
\mathrm{TS} 13 \mathrm{a}\left({ }^{1} \mathrm{~A}\right) \rightarrow \mathrm{NH}_{3} \mathrm{CH}_{2} \mathrm{CHO}^{+}\left({ }^{1} \mathrm{~A}^{\prime}\right)+\mathrm{H}_{2}\left({ }^{1} \Sigma_{\mathrm{g}}^{+}\right) \\
\text {Path e.1 } \\
\mathrm{TS} 14 \mathrm{a}\left({ }^{1} \mathrm{~A}\right) \rightarrow \mathrm{c}-\mathrm{NH}_{2} \mathrm{CH}_{2} \mathrm{CHOH}^{+}\left({ }^{1} \mathrm{~A}^{\prime}\right)+\mathrm{H}_{2}\left({ }^{1} \Sigma_{\mathrm{g}}^{+}\right) \\
\text {Path e. } 2
\end{array}\right.
\end{aligned}
$$

Formation of $\mathrm{N}$-protonated amino acetaldehyde is exothermic, $\Delta H=-51.33 \mathrm{kcal} \mathrm{mol}^{-1}$ at the $\operatorname{CCSD}(\mathrm{T}) /$ aug-cc-pVTZ level, but presents a net activation barrier $\left(\mathrm{TS} 13 \mathrm{a}\left({ }^{1} \mathrm{~A}\right)\right.$ is located $9.19 \mathrm{kcal} \mathrm{mol}^{-1}$ above the reactants at the $\operatorname{CCSD}(\mathrm{T}) / \mathrm{aug}-\mathrm{cc}-$ pVTZ level), and therefore it is not feasible under interstellar conditions. Nevertheless, formation of the cis conformer of O-protonated amino acetaldehyde is possible under interstellar conditions; Path e. 2 is exothermic $\left(\Delta H=-24.25 \mathrm{kcal} \mathrm{mol}^{-1}\right.$ at the CCSD(T)/aug-cc-pVTZ level) and barrier free (transition state related to molecular hydrogen elimination, $\operatorname{TS} 14 \mathrm{a}\left({ }^{1} \mathrm{~A}\right)$, is located $5.72 \mathrm{kcal} \mathrm{mol}^{-1}$ below the reactants at the $\operatorname{CCSD}(\mathrm{T}) /$ aug-cc-pVTZ level).

Intermediate $\mathrm{I} 7 \mathrm{a}\left({ }^{1} \mathrm{~A}\right)$ can isomerize into its conformational isomer I8a $\left({ }^{1} \mathrm{~A}^{\prime}\right)$ through transition state $\operatorname{TS} 15 \mathrm{a}\left({ }^{1} \mathrm{~A}\right)$, clearly located below the reactants $\left(-67.13 \mathrm{kcal} \mathrm{mol}^{-1}\right.$ at the $\operatorname{CCSD}(\mathrm{T}) /$ aug-cc-pVTZ level). Then, from intermediate I8a $\left({ }^{1} \mathrm{~A}^{\prime}\right)$, we can obtain the three isomers of protonated amino acetaldehyde following the paths

$$
\begin{aligned}
& \mathrm{I} 7 \mathrm{a}\left({ }^{1} \mathrm{~A}\right) \rightarrow \operatorname{TS} 15 \mathrm{a}\left({ }^{1} \mathrm{~A}\right) \rightarrow \operatorname{I8a}\left({ }^{1} \mathrm{~A}^{\prime}\right) \\
& \rightarrow\left\{\begin{array}{r}
\mathrm{TS} 16 \mathrm{a}\left({ }^{1} \mathrm{~A}\right) \rightarrow \mathrm{NH}_{3} \mathrm{CH}_{2} \mathrm{CHO}^{+}\left({ }^{1} \mathrm{~A}^{\prime}\right)+\mathrm{H}_{2}\left({ }^{1} \Sigma_{\mathrm{g}}^{+}\right) \\
\text {Path f.1 } \\
\mathrm{TS} 17 \mathrm{a}\left({ }^{1} \mathrm{~A}\right) \rightarrow \mathrm{NH}_{2} \mathrm{CHCH}_{2} \mathrm{OH}^{+}\left({ }^{1} \mathrm{~A}^{\prime}\right)+\mathrm{H}_{2}\left({ }^{1} \Sigma_{\mathrm{g}}^{+}\right) \\
\text {Path f.2 } \\
\mathrm{TS} 18 \mathrm{a}\left({ }^{1} \mathrm{~A}\right) \rightarrow \mathrm{t}-\mathrm{NH}_{2} \mathrm{CH}_{2} \mathrm{CHOH}^{+}\left({ }^{1} \mathrm{~A}^{\prime}\right)+\mathrm{H}_{2}\left({ }^{1} \Sigma_{\mathrm{g}}^{+}\right) \\
\text {Path f.3 }
\end{array}\right.
\end{aligned}
$$

We can see in Figure 3 that transition states $\mathrm{TS} 16 \mathrm{a}\left({ }^{1} \mathrm{~A}\right)$ and TS17a $\left({ }^{1} \mathrm{~A}\right)$, corresponding to molecular hydrogen abstraction from I8a $\left({ }^{1} \mathrm{~A}\right)$, are located above the reactants $(28.41$ and
$6.07 \mathrm{kcal} \mathrm{mol}^{-1}$ at the $\operatorname{CCSD}(\mathrm{T}) /$ aug-cc-pVTZ level, respectively). Therefore, both paths $f .1$ and $f .2$, are not viable under interstellar conditions. However, formation of O-protonated amino acetaldehyde in its trans conformation (Path f.3) is an exothermic $\left(\Delta H=-35.73 \mathrm{kcal} \mathrm{mol}^{-1}\right.$ at the $\operatorname{CCSD}(\mathrm{T}) /$ aug-cc$\mathrm{pVTZ}$ level) and barrier free process ( $\mathrm{TS} 18 \mathrm{a}\left({ }^{1} \mathrm{~A}\right)$ involved in the molecular hydrogen elimination is located $-14.10 \mathrm{kcal} \mathrm{mol}^{-1}$ below the reactants at the $\operatorname{CCSD}(\mathrm{T}) /$ aug-cc-pVTZ level), therefore feasible in space.

Finally, intermediate $\mathrm{I} 7 \mathrm{a}\left({ }^{1} \mathrm{~A}\right)$ can also isomerize to $\mathrm{I} 9 \mathrm{a}\left({ }^{1} \mathrm{~A}\right)$ through transition state $\operatorname{TS} 19 \mathrm{a}\left({ }^{1} \mathrm{~A}^{\prime}\right)$, where the insertion of the $\mathrm{NH}_{2}$ group into the $\mathrm{C}-\mathrm{C}$ bond takes place. From this isomer, we can reach protonated isomers of $\mathrm{N}$-methyl formamide. These processes can be summarized as

$$
\begin{aligned}
& \mathrm{I7a}\left({ }^{1} \mathrm{~A}\right) \rightarrow \mathrm{TS} 19 \mathrm{a}\left({ }^{1} \mathrm{~A}\right) \rightarrow \mathrm{I} 9 \mathrm{a}\left({ }^{1} \mathrm{~A}\right) \\
& \rightarrow\left\{\begin{array}{l}
\mathrm{TS} 20 \mathrm{a}\left({ }^{1} \mathrm{~A}\right) \rightarrow \mathrm{CH}_{3} \mathrm{NHCHOH}^{+}\left({ }^{1} \mathrm{~A}^{\prime}\right)+\mathrm{H}_{2}\left({ }^{1} \Sigma_{\mathrm{g}}^{+}\right) \\
\mathrm{TS} 21 \mathrm{a}\left({ }^{1} \mathrm{~A}\right) \rightarrow \mathrm{CH}_{2} \mathrm{NH}_{2} \mathrm{CHO}^{+}\left({ }^{1} \mathrm{~A}^{\prime}\right)+\mathrm{H}_{2}\left({ }^{1} \Sigma_{\mathrm{g}}^{+}{ }^{+}{ }_{\text {Path g.1 }} .2\right.
\end{array}\right.
\end{aligned}
$$

It is readily seen in Figure 3 that even though formation $\mathrm{O}$ and $\mathrm{N}$-protonated $\mathrm{N}$-methyl formamide are clearly exothermic processes $\left(-58.99\right.$ and $-43.23 \mathrm{kcal} \mathrm{mol}^{-1}$ at $\mathrm{CCSD}(\mathrm{T}) / \mathrm{aug}$ cc-pVTZ level, respectively), formation of $\mathrm{I} 9 \mathrm{a}\left({ }^{1} \mathrm{~A}\right)$ presents a high activation barrier (TS19a $\left({ }^{1} \mathrm{~A}\right)$ is located $64.89 \mathrm{kcal} \mathrm{mol}^{-1}$ above the reactants at the $\operatorname{CCSD}(\mathrm{T}) /$ aug-cc-pVTZ level), and consequently, the reaction between $\mathrm{CH}_{5}^{+}$and formamide cannot be a source of protonated $\mathrm{N}$-methyl formamide in the interstellar medium.

The detailed analysis of the singlet potential energy surface, $\left[\mathrm{C}_{2} \mathrm{H}_{8} \mathrm{NO}\right]^{+}$, shows that protonated acetamide can be formed under interstellar conditions from the reaction of $\mathrm{CH}_{5}^{+}$with formamide. Paths $a .1, a .2$, and $b$ giving the two conformers of O-protonated acetamide isomer are exothermic and barrierfree processes (see Figure 2). In addition, the two conformations of protonated amino acetaldehyde can also be reached from this reaction through Paths e.2 and f.3 (see Figure 3). It should be pointed out that both isomers, as in the case of O-protonated acetamide, could be found in space because isomerization involves an energy barrier of $4.26 \mathrm{kcal} \mathrm{mol}^{-1}$, estimated at the CCSD(T)/aug-cc-pVTZ level. On the other hand, our results show that precursors of $\mathrm{N}$-methyl formamide are not formed in the reaction of $\mathrm{CH}_{5}^{+}$with formamide. This conclusion seems in agreement with the fact that the higher-lying isomer of acetamide, $\mathrm{N}$-methyl formamide, has not been detected in space in spite of being searched for in the same sources where acetamide was observed (Halfen et al. 2011).

Recently, Halfen et al. (2011) have pointed out that the similarity between the abundances and distribution of $\mathrm{CH}_{3} \mathrm{CONH}_{2}$ and $\mathrm{NH}_{2} \mathrm{CHO}$ suggests a synthetic connection. Our results show that such a connection exists because acetamide can be obtained in space from formamide. In addition, protonated amino acetaldehyde, a glycine precursor, also can be formed. Therefore, biological molecules could be formed from formamide. In the same way, given the relatively large abundance of acetamide, this molecule could also be a source of more complex molecules.

\section{CONCLUSIONS}

In the present work, we theoretically analyze the viability in the interstellar medium of two gas-phase ion-molecule reactions, namely, $\mathrm{NH}_{4}^{+}+\mathrm{H}_{2} \mathrm{CO}$ and $\mathrm{CH}_{5}^{+}+\mathrm{NH}_{2} \mathrm{CHO}$, which 
could produce formamide and acetamide precursors in space, respectively. A theoretical estimation of the reaction enthalpies for the two reactions considering several products is reported. In order to determine if exothermic processes are barrier free, we perform an analysis of the corresponding potential energy surfaces.

The calculated reaction enthalpies for the reaction between ammonium cation and formaldehyde show that only formation of O-protonated formamide $\left(\mathrm{NH}_{2} \mathrm{CHOH}^{+}\left({ }^{1} \mathrm{~A}^{\prime}\right)\right)$ is an exothermic process. However, the analysis of the potential energy surface shows that this process is not viable under interstellar conditions because all the paths leading to that product present net activation energies. Therefore, this reaction cannot be considered as a possible source of formamide in space. Considering our previous results for the gas-phase reactions of ionized, protonated, and neutral hydroxylamine with formaldehyde (Redondo et al. 2014), we can conclude that other alternative routes, such as reactions on the surface of interstellar grains, should be considered.

For the second reaction, $\mathrm{CH}_{5}^{+}+\mathrm{NH}_{2} \mathrm{CHO}$, formation of both conformers of O-protonated acetamide and $\mathrm{N}$-protonated acetamide are clearly exothermic processes $(\Delta H=-71.33$, -68.63 , and $-55.80 \mathrm{kcal} \mathrm{mol}^{-1}$ at the $\operatorname{CCSD}(\mathrm{T}) / \mathrm{aug}-\mathrm{cc}-\mathrm{pVQZ}$ level, respectively). In addition, processes giving $\mathrm{O}-$ or $\mathrm{N}$-protonated $\mathrm{N}$-methyl formamide, the oxygen protonated of the enolic form of acetamide, and $\mathrm{O}$ - or N-protonated amino acetaldehyde are also exothermic. The detailed analysis of the singlet potential energy surface shows that formation of O-protonated acetamide $\left(\mathrm{CH}_{3} \mathrm{COHNH}_{2}^{+}\left({ }^{1} \mathrm{~A}^{\prime}\right)\right)$ is viable under interstellar conditions (exothermic and barrier-free process). Both conformers of O-protonated acetamide could be obtained. In addition, the two conformations of protonated amino acetaldehyde (a possible precursor of glycine) can also be reached through this reaction. Our results also show that precursors of $\mathrm{N}$-methyl formamide (a high-lying isomer of acetamide) are not formed in the reaction of $\mathrm{CH}_{5}^{+}$with formamide. We can conclude that acetamide could be synthetized from formamide in the interstellar space. This synthetic connection could explain the similarity found between their abundances and distribution, as was suggested previously by Halfen et al. (2011).

Finally, taking into account the results of the present study, as well as previous works on formamide production (Redondo et al. 2014) and glycylglycine formation (Redondo et al. 2013), it seems that formation of a peptide bond through gas-phase ion-molecule reactions is rather difficult in space. However, once a peptide bond exists, more complex molecules could be obtained through gas-phase reactions.

Financial support from the Spanish "Ministerio de Educación y Ciencia" (grant QCT2010-16864) and the "Junta de Castilla y León” (grant VA077U13) is gratefully acknowledged.

\section{REFERENCES}

Ceccarelli, C., Loinard, L., Castets, A., Faure, A., \& Lefloch, B. 2000, A\&A, 362,1122

Cernicharo, J., Tercero, B., Fuente, A., et al. 2013, ApJL, 771, L10

Chen, L., \& Woon, D. E. 2011, JPCA, 115, 5166

Dunning, T. H. 1989, JChPh, 90, 1007

Frisch, M. J., Trucks, G. W., Schlegel, H. B., et al. 2009, Gaussian 09 (Wallingford CT: Gaussian, Inc.)

Fukui, K. 1981, Acc. Chem. Res., 14, 363

Garrod, R. T., Widicus Weaver, S. L., \& Herbst, E. 2008, ApJ, 682, 283

Halfen, D. T., Ilyushin, V., \& Ziurys, L. M. 2011, ApJ, 743, 60

Hollis, J. M., Snyder, L. E., Suenram, R. D., \& Lovas, F. J. 1980, ApJ, 241, 1001

Hollis, J. M., Pedelty, J. A., Boboltz, D. A., et al. 2003a, ApJL, 596, L235

Hollis, J. M., Pedelty, J. A., Snyder, L. E., et al. 2003b, ApJ, 588, 353

Hollis, J. M., Lovas, F. J., Remijan, A. J., et al. 2006, ApJL, 643, L25 Irvine, W. 1998, OLEB, 28, 365

Jones, B. M., Bennett, C. J., \& Kaise, R. I. 2011, ApJ, 734, 78

Kuan, J.-Y., Charnley, S. B., Huang, H.-C., Tseng, W.-L., \& Kisiel, Z. 2003, ApJ, 593,848

Lattelais, M., Pauzat, F., Ellinger, Y., \& Ceccarelli, C. 2010, A\&A, 519, A30

Møller, C., \& Plesset, M. 1934, PhRv, 46, 618

Nguyen, V. S., Abbott, H. L., Dawley, M. M., et al. 2011, JPCA, 115, 841

Nguyen, V. S., Orlando, T. M., Leszczynski, J., \& Nguyen, M. T. 2013, JPCA, 117,2543

Quan, D., \& Herbst, E. 2007, A\&A, 474, 521

Raghavachari, K., Trucks, G. W., Pople, J. A., \& Head-Gordon, M. 1989, CPL, 157,479

Redondo, P., Barrientos, C., \& Largo, A. 2014, ApJ, 780, 181

Redondo, P., Martinez, H., Cimas, A., Barrientos, C., \& Largo, A. 2013, PCCP, 15,13005

Rubin, R. H., Swenson, G. W., Benson, R. C., et al. 1971, ApJL, 169, L39

Saladino, R., Crestini, C., Pino, S., Costanzo, G., \& Di Mauro, E. 2012, Phys. Live Rev., 9, 84

Synder, L. E., Buhl, D., Zuckerman, B., \& Palmer, P. 1969, PhRvL, 22, 679

Snyder, L. E., Lovas, F. J., Hollis, J. M., et al. 2005, ApJ, 619, 914

Woon, D. E. 2001, IJQC, 88, 226

Woon, D. E., \& Dunning, T. H. 1993, JChPh, 98, 1358 